\title{
Figures and Charts
}

Figures

1.1 Page from early Qur'an, ca. 90027

1.2 Qur'an leaf with interlinear Persian translation 69

2.1 Twin Nabatean tombs at Mada'in Salih 86

2.2 Nabatean monument at Petra 88

3.1 The Seven Sleepers, from the Jami al-tawarikh of Rashid al-Din 124

3.2 Hellenistic coin representing Alexander with ram's horn 134

3.3 Miniature painting of Alexander's wall, from a Khamsa of Nizami 135

4.1 Mary in the Temple, Kariye Camii, Istanbul 185

\section{Charts}

1.1 Numbers, Names, and Initial Letters of Suras of the Qur'an with Numbering in Chronologies of Nöldeke and the Egyptian Edition 39

1.2 Nöldeke's Qur'anic Chronology in Canonical Order 44 
